\title{
Response to Pickett and Wilkinson (2015)
}

\author{
Simone Rambotti \\ University of Arizona
}

Pickett and Wilkinson (2015b) advance two main critiques of my article (Rambotti, 2015): that I ignore much literature, and that I mistakenly believe that the measures of poverty and inequality are different. Before addressing these points, I emphasize that my criticism was not ill-intentioned. Indeed, I share P\&W's concern for excessive income inequality, I commend their effort to attract general attention to this issue, and I pay homage to them with my title choice. The spirit (or bubble) level is an instrument: calibrating an instrument maintains (or improves) its accuracy, and is predicated upon the calibrated instrument having validity and usefulness. I thus welcome their attempt to recalibrate me.

Their first criticism can be safely rejected. I cited several reviews, including some referenced by P\&W in their response (Kondo et al., 2009; Pickett \& Wilkinson, 2015a). Indeed, there are more, but their reading still does not grant the hegemonic narrative of the field that $\mathrm{P} \& \mathrm{~W}$ advance. In fact, scholars have found that the "relationship between income inequality and health is unclear" (Macinko, Shi, Starfield, \& Wulu, 2003, p. 407), that "the published evidence so far is by no means conclusive" (Subramanian \& Kawachi, 2004, p. 78), and that, net of partially supportive results, $30 \%$ of the remainder are wholly unsupportive (Wilkinson \& Pickett, 2006), described subsequently as "a small proportion of negative findings" (Pickett \& Wilkinson, 2015a, p. 318). Scholars provided important mechanism tests, but also highlighted that the findings are still not conclusive, and that the mechanisms themselves are not mutually exclusive (Elgar, 2010; Elgar \& Aitken, 2011; Layte, 2012).

As for the second criticism, I refer the reader to my discussion of the relationship between income inequality and poverty (section 3), where I acknowledge that the two are "clearly dependent" (Rambotti, 2015, p. 125), while also distinguishing between headcount and gap measures that catch respectively breadth and depth of the income distribution. In section 4.2 I refer to the analysis of Kawachi and Kennedy (1997) on the choice of income inequality indicators. I invite the reader to compare Table 2 in their article (Kawachi \& Kennedy, 1997, p. 1124) with Table 1 in mine (Rambotti, 2015, p. 
126) to appreciate the difference in the magnitude of the correlation coefficients. P\&W also suggest that previous multilevel analyses controlled the effect of individual incomes, thus representing a better alternative to my analysis. P\&W here fail to recognize the collective nature of poverty as a social fact. This is highlighted, for instance, by the analyses that followed the experiment Moving to Opportunity, which show the positive effect of (low-poverty) neighborhood environment on health even without an increase of income and earnings (Chetty, Hendren, \& Katz, 2015; Kling, Liebman, \& Katz, 2007; Ludwig et al., 2011, 2012).

To conclude, I emphasize that none of the points raised here and in the original article are incompatible with the fact that excessive income inequality has adverse social effects, with the existence of social gradients, or with psychological explanations. However, as we look at the bigger picture and analyze it in its complexity, we should strive to avoid reductionism. There is an "enormous and well-developed body of social science literature" (Beckfield \& Krieger, 2009, p. 153) that can help shed light on the structural side of this story, which until now has been too readily dismissed. 


\section{References}

Beckfield, J., \& Krieger, N. (2009). Epi + demos + cracy: Linking Political Systems and Priorities to the Magnitude of Health Inequities-Evidence, Gaps, and a Research Agenda. Epidemiologic Reviews, 31(1), 152-177.

http://doi.org/10.1093/epirev/mxp002

Chetty, R., Hendren, N., \& Katz, L. F. (2015). The Effects of Exposure to Better

Neighborhoods on Children: New Evidence from the Moving to Opportunity

Experiment (Working Paper No. 21156). National Bureau of Economic Research. https://doi.org/10.3386/w21156

Elgar, F. J. (2010). Income inequality, trust, and population health in 33 countries. American Journal of Public Health, 100(11), 2311.

http://doi.org/10.2105/AJPH.2009.189134

Elgar, F. J., \& Aitken, N. (2011). Income inequality, trust and homicide in 33 countries. The European Journal of Public Health, 21(2), 241-246.

http://doi.org/10.1093/eurpub/ckq068

Kawachi, I., \& Kennedy, B. P. (1997). The relationship of income inequality to mortality: does the choice of indicator matter? Social Science \& Medicine, 45(7), 1121-1127. http://doi.org/10.1016/S0277-9536(97)00044-0

Kling, J. R., Liebman, J. B., \& Katz, L. F. (2007). Experimental Analysis of Neighborhood Effects. Econometrica, 75(1), 83-119. http://doi.org/10.1111/j.14680262.2007.00733.x

Kondo, N., Sembajwe, G., Kawachi, I., van Dam, R. M., Subramanian, S. V., \& Yamagata, Z. (2009). Income inequality, mortality, and self rated health: metaanalysis of multilevel studies. BMJ: British Medical Journal, 339. http://doi.org/10.1136/bmj.b4471

Layte, R. (2012). The association between income inequality and mental health: testing status anxiety, social capital, and neo-materialist explanations. European Sociological Review, 28(4), 498-511. http://doi.org/10.1093/esr/jcr012

Ludwig, J., Duncan, G. J., Gennetian, L. A., Katz, L. F., Kessler, R. C., Kling, J. R., \& Sanbonmatsu, L. (2012). Neighborhood effects on the long-term well-being of lowincome adults. Science, 337(6101), 1505-1510. http://doi.org/10.1126/science.1224648 
Ludwig, J., Sanbonmatsu, L., Gennetian, L., Adam, E., Duncan, G. J., Katz, L. F., ... Whitaker, R. C. (2011). Neighborhoods, obesity, and diabetes - a randomized social experiment. New England Journal of Medicine, 365(16), 1509-1519. http://doi.org/10.1056/NEJMsa1103216

Macinko, J. A., Shi, L., Starfield, B., \& Wulu, J. T. (2003). Income inequality and health: a critical review of the literature. Medical Care Research and Review, 60(4), 407452. http://doi.org/10.1177/1077558703257169

Pickett, K. E., \& Wilkinson, R. G. (2015a). Income inequality and health: A causal review. Social Science \& Medicine, 128, 316-326. http://doi.org/10.1016/j.socscimed.2014.12.031

Pickett, K. E., \& Wilkinson, R. G. (2015b). Recalibrating Rambotti: Disentangling concepts of poverty and inequality. Social Science \& Medicine, 139, 132-134. http://doi.org/10.1016/j.socscimed.2015.07.005

Rambotti, S. (2015). Recalibrating the spirit level: An analysis of the interaction of income inequality and poverty and its effect on health. Social Science 6 Medicine. http://doi.org/10.1016/j.socscimed.2015.02.026

Subramanian, S. V., \& Kawachi, I. (2004). Income inequality and health: what have we learned so far? Epidemiologic Reviews, 26(1), 78-91. http://doi.org/10.1093/epirev/mxh003

Wilkinson, R. G., \& Pickett, K. E. (2006). Income inequality and population health: a review and explanation of the evidence. Social Science $\&$ Medicine, 62(7), 17681784. http://doi.org/10.1016/j.socscimed.2005.08.036 